\title{
新时期高职院校学生教育管理工作探索与实践
}

王迎春

金肯职业技术学院

DOI:10.32629/jief.v2i3.821

[摘 要] 在教育改革的背景下, 高职院校学管人员将新时期管理理念落实在实际教育管理工作中, 这对促进高职学生的发展有着十分重要的 意义。所以学管人员想要培养出全面发展的学生, 就应该在日常班级的管理中重视渗透新时期管理理念。这不但有助于学生更好的发挥自己 在课堂的主体作用, 对促进学生全面发展也有着十分重要的意义。而这也有助于学管人员培育出更加优秀的人才, 但是在实际的高职院校学 生管理工作中, 学管人员使用新时期管理理念的情况并不明显。基于此, 本文将对新时期高职院校学生教育管理工作探索与实践进行深入的 探讨，以供从事相关工作的人员借鉴参考。

[关键词] 高职院校; 新时期; 教育管理工作

高职院校学生的人生观、价值观还有待提高, 而高职院校学管人员 将新时期管理理念落实在实际的教育管理工作中, 对促进高职院校学生 的全面发展, 促使高职院校学生认真学习文化知识, 树立正确的价值观 念有着十分重要的意义 ${ }^{[1]}$ 。而且, 学管人员及时的将以学生为本的管理 理念落实在实际工作中, 对完善学生的品格, 促进学生全面发展有着十 分重要的意义。而高职院校的学生得到全面发展, 有助于其更好的融入 社会中, 为社会的稳定与发展贡献自己的力量。而如何有效的做到的这 一点, 是许多学管人员密切关注的问题, 下面将对此进行详细的阐述。

\section{1 落实新时期管理理念以及管理新策略}

在高职院校的教育管理工作中, 融入新时期管理理念进行教育管理 工作, 对提升教育管理工作的质量, 促进学生更好的发展有着十分重要 的意义 ${ }^{[2]}$ 。学管人员想要有效的将新时期管理理念落实在实际教育管理 工作中, 就要认识新时期管理理念对培育学生成才的重要意义。从心理 上改变传统的管理观念, 在和学生沟通交流的时候要将自己放在和学生 平等的位置上。此外, 学管人员在进行教育管理工作的时候, 要积极地 了解学生的学习状态、以及学生的性格, 在和学生进行沟通交流的时候 要注意根据学生的性格特点改变表达方式, 以此让新时期管理理念真正 的落实在高职院校教育管理工作中, 与学生做到真正有效的交流。在交 流的过程中, 学管人员也要重视鼓励学生张扬个性, 这对培养学生全面 发展有着重要的意义, 而学管人员在落实新时期管理理念教育的时候, 要保证所使用的管理方法是科学合理的, 以此让高职院校班级学风建设 本质上得到有效提升。而为了有效的提升新时期高职院校的教学管理水 平, 校方一定要积极地组织一些专业的教育研究人员定期的给学管人员 开办讲座, 对学管人员在进行教育管理工作中遇到的问题进行分析, 给 予学管人员专业的意见。这不但能有效的提升学管人员的教育管理工作 的质量, 而且对学管人员更好的将新时期管理理念落实在教育管理工作 中也有着十分积极的意义 ${ }^{[3]}$ 。

\section{2 借助信息技术更好的进行高职教育管理工作}

信息技术不但在教学上有着极大的优势, 对更好的在教育管理工作 中落实新时期管理理念也有着十分重要的意义。所以学管人员想要提升 新时期管理理念的质量, 就要重视借助信息技术建立班级微信群。这有
助于学管人员及时的了解学生的情况, 这对学管人员根据学生的情况更 好的落实教育管理工作有着十分积极的意义。而且通过微信群有助于学 管人员和学生之间及时有效的进行沟通交流, 这对促进学生更好的发展 也有着十分积极的意义。学管人员有效的借助微信群可以更好的对学生 进行思想教育, 这有助于学生更好的认识遵守校园规章制度的重要性, 这对有效的提升高职院校班级管理水平有着十分重要的意义。而且使用 这种方式进行管理, 使学生受到了充分的尊重, 有助于学生从客观的角 度看待自身的学习, 这对学生养成良好的学习习惯有着十分重要的意义。 由于大部分高职院校生源录取成绩较低, 所以在步入高职学校后, 学管 人员应该着重对生源特点进行分析, 选择恰当的管理方式, 比如可以结 合生源的优势和劣势为其制定合理的发展方向, 尽可能的为其提供帮助。

此外, 学管人员要重视贯穿新时期管理理念, 对学生身上的优点及 时的给予肯定和表扬, 这有助于更好的提升学生主动学习的积极性, 这 对学生学习到更多的知识, 日后得到更好的建设祖国有着十分积极的意 义。除此之外, 学管人员在组建班级活动的时候, 也要充分了解学生在 学习之外的特长, 让能歌善舞的学生积极地参与到活动中, 这有助于学 生更好的找到自己的位置, 更好的将自身的作用发挥出来, 同时促使学 管人员更有效的进行教育管理工作。在落实新时期管理理念的过程中, 教师也要积极地深入了解、挖掘新时期管理理念的价值, 这有助于学管 人员更好的将新时期管理理念落实在实际工作中, 这对提升高职院校教 育管理工作质量, 促使学生得到更好的发展有着十分重要的意义 ${ }^{[4]}$ 。

\section{3 重视给学生进行心理疏导、施行品质化教育管理}

学管人员要想有效的进行教育管理工作, 就要重视给学生做心理疏 导。因为高职的学生毕业后往往直接进入到社会, 面临着较大的心理压 力, 做好心理疏导, 再进行相应的教育管理工作, 才更有针对性也更有 效率。对学习优异的学生做心理疏导的时候, 主要内容应该是给予学生 肯定, 积极地解答学生的困惑鼓励学生树立自信。对自己前途迷茫的学 生, 应该及时的调整学生的心态, 帮助学生重新树立信念, 及时的肯定 和鼓励学生。而对于有些自暴自弃的学生, 一定要向学生表明作为学管 人员不抛弃, 不放弃的态度, 引导学生正确的看待人生。除此之外, 学 管人员设置合理的奖罚制度对提升学生的学习积极性也有着十分重要的 
意义。但是学管人员要注意, 设计奖罚制度的标准不应该是成绩的优劣, 而应该是进步的大小, 只有这样, 才能促使每一个学生都能在进步的时 候体会到成功的喜悦。而学生不断地受到奖励, 不但能提升学生学习的 信心而且有助于学生看到人生的希望, 进而更认真的学习从而促使学生 不断的超越自己不断的得到进步。而这种教育管理工作模式, 不但能有 效的提升管理质量, 而且对促进学生身心健康的成长也有着十分积极的 意义。

所谓的品质化教育管理, 也就是学管人员开展日常学生管理的时候 要忠实对学生进行安全防护教育, 提升学生的自我保护意识, 并引导学 生树立正确的价值观念、人生观, 引导学生正确的对待自己的虚荣心, 减少互相攀比的不良心理习惯, 提升学生的道德操守。同时, 也要让学 生认识到保护自身信息安全的重要性, 以及维护自己信用的重要价值, 引导学生理性消费不要落入到冲动消费的陷阴中。要让学生认识到遵纪 守法的重要性, 高职院校可以根据自身的实际情况以及教育管理工作的 需要, 邀请专业的人员进行教育讲座, 并根据学生的实际情况建立违纪 资料库, 这有助于让学生认识到遵纪守法的重要性, 这对高职院校更好 的开展教育管理工作有着十分重要的意义。

\section{4 结束语}

总而言之, 学管人员在高职院校教育管理工作中落实新时期管理理 念有着十分重要的意义。所以, 学管人员应该认识到新时期管理理念的 重要性, 并重视增加和学生之间的交流沟通, 让新时期管理理念发挥的 作用充分的发挥在高职院校教育管理工作中。学管人员也需要不断的提 升自身的专业水平, 根据学生的实际学习情况, 制定科学合理的教育管 理工作方案, 只有这样, 学管人员才能有效的提升教育管理工作的效率, 为社会培育出更多优秀的人才, 以此更好的推动社会的发展。

\section{[参考文献]}

[1]徐浩.新时期高职院校学生教育管理工作探索与实践 [J]. 智库时 代,2019(21):68+78.

[2]韩春乐.新时期高职院校学生教育管理工作探索与实践 [J]. 天津 职业院校联合学报,2019,21(03): 74-78.

[3]何李莉.新时期高职院校学生管理工作面临的新问题及对策 [J]. 教育现代化,2018,5(45):297-298+305.

[4]潘晓娜.高职院校学生教育管理工作优化路径研究 [J].新西 部,2018(15):136+133.

作者简介：王迎春（1989-)，女，汉族，河南周口人，本科， 实习研究员 (初级), 研究方向: 高校学生管理、高校宣传。 